Смелова Алена Андреевна

кандидат социологических наук, доцент кафедры экономической социологии Санкт-Петербургского государственного университета

\section{СОЦИАЛЬНЫЕ ПРАКТИКИ ПИТАНИЯ ДЕТЕЙ: ГРУДНОЕ ВСКАРМЛИВАНИЕ КАК СОЦИАЛЬНО-ЭКОНОМИЧЕСКАЯ ПРОБЛЕМА [1]}

\section{Аннотация:}

В статье рассматривается проблема десакрализации естественного грудного вскармливания как результата развития международной системы «молочного капитализма». Вокруг грудного вскармливания складывается культура бутилированного вскармливания, $\boldsymbol{m}$. е. кормления ребенка при помощи бутылки и соски детскими смесями, донорским молоком или сцеженным молоком матери. Происходum переход к технологичному кормлению, возрастает спрос на сакральные биоресурсы - человеческое молоко как важнейший биологический и соци ально-экономический ресурс, превращая естественное грудное вскармливание в альтернативную социальную практику питания детей раннего возраста. Предпринята попытка проанализировать социально-статусное измерение грудного вскармливания женшинами разных социальных слоев. Показана связь между практиками вскармливания детей раннего возраста, уровнем заболевае мости и государственными расходами на здравоохранение. Делается вывод, что существующая дискуссия о правильных практиках вскармливания детей лежит не в плоскости здорового питания и нормального воспроизводства населения, а в области подержания и воспроизводства международной системы «молочного капитализма».

Ключевые слова:

социальные практики питания детей, грудное вскармливание, бутилированное вскармливание донорское молоко, банк грудного молока, инициатива ВОЗ по грудному вскармливанию, мифологизация молока, десакрализация естественного грудного вскармливания.
Smelova Alena Andreevna

PhD in Social Science, Associate Professor, Economic Sociology Department, Saint Petersburg State University

SOCIAL CHILD FEEDING PRACTICES: BREASTFEEDING AS A SOCIAL AND ECONOMIC PROBLEM [1]

Summary:

The study deals with the problem of natural breastfeeding desacralization as a result of the development of the international system of milk capitalism. There is a bottle-feeding culture, i.e. feeding a child with a bottle and a nipple with infant formula, donor milk or expressed mother's milk, in the context of breastfeeding. One can observe a transition to technological feeding and a growing demand for sacred biological resource (human milk as the major biological, social and economic resource), turning natural breastfeeding into an alternative social practice of feeding infants. An attempt is made to analyze the social status of breastfeeding by women of different social strata. Besides, the research demonstrates the relationship of the infant feeding practices with the morbidity rate and public expenditure on health. It is concluded that the current discussion about the proper child feeding practices is not within the healthy nutrition and proper reproduction of the population but the maintenance and reproduction of the international system of milk capitalism.
Keywords: social child feeding practices, breastfeeding, bottlefeeding, donor milk, breast milk bank, Baby-friendly Hospital Initiative by the WHO, mythologization of milk, desacralization of the natural breastfeeding.

Сегодня естественное грудное вскармливание в системе общественных ценностей играет далеко не первостепенную роль, уступив ее после Второй мировой войны бутилированному вскармливанию детскими молочными смесями. Так, Мадонна с младенцем, символ материнства и женственности эпохи Возрождения, сменилась Мадонной - поп-певицей, символом эротизма и сексуальной революции XX в., а женская грудь из единственного источника естественного питания ребенка превратилась в сексуальный объект, установив негласный запрет на ее демонстрацию в общественных местах. Однако в последнее время актуальность грудного вскармливания возвращается по причине ее активной популяризации рядом всемирных организаций: Всемирной организацией здравоохранения, Международной молочной лигой, Всемирной организацией грудного кормления (World Alliance for Breastfeeding Action - WABA), Ассоциацией консультантов по естественному вскармливанию (АКЕВ), Международной ассоциацией консультантов по лактации, рядом международных волонтерских проектов - например, Human Milk for Human Babies (HM4HВ) и др.

Проблематика грудного вскармливания активно обсуждается в научной литературе не одно десятилетие. Так, исследования 1990-х гг. [2] фокусировались на вопросе разрушения культуры естественного грудного вскармливания и развитии культуры бутилированного вскармливания искусственными смесями и ее высокой экономической оценке. В начале 2000-х гг. грудное вскармливание рассматривалось как право и свободный выбор женщины, как женское искусство 
и субкультура [3]. Затем стали появляться альтернативные подходы, призванные рационализовать процесс грудного вскармливания и освободить женщину: нестрогие системы питания для кормящих матерей и их право на отдых и путешествия, совместимость материнства с семейной и сексуальной жизнью, возможностью продолжения трудовой деятельности и развития карьеры все, что может быть доступно при большом запасе сцеженного грудного молока [4].

В центре внимания современных ученых находятся вопросы техники кормления и сцеживания [5], возвращения на работу и организации кормления ребенка раннего возраста на рабочем месте, перехода на бутилированное вскармливание, сокращения ночных кормлений, введения прикорма, эмоциональной подготовки ребенка к передаче его няне [6], употребления лекарственных препаратов во время грудного вскармливания [7]. Описываются способы увеличения лактации (сцеживание, применение трав, лекарств, специальной еды, альтернативной терапии) дома и при выходе на работу - при заготовке грудного молока на день, техники прекращения и возобновления лактации [8], техники грудного вскармливания для нерожавших женщин, которые усыновили ребенка или воспользовались услугами суррогатных матерей [9]. Появляются работы, рассматривающие грудное вскармливание в международной перспективе и раскрывающие связанные с ним вопросы традиций, ценностей и убеждений в отношении грудного вскармливания, образа «хорошей матери» в современном обществе стран Азии и Африки, Австралии, США и Великобритании, социальной политики в области охраны материнства и детства, грудного вскармливания в эпоху ВИЧ, влияния миграции на культуру материнства, трудовой занятости женщин и управления лактацией [10].

Также большой пласт современной литературы адресован специалистам, которые планируют стать консультантами по грудному вскармливанию: это различные информационные ресурсы для подготовки к сертификации [11], кейсы международных консультантов по лактации [12], данные, посвященные анатомическим, фризиологическим, биохимическим, пищевым, иммунологическим и психологическим аспектам лактации человека, техникам клинического ведения грудного вскармливания [13].

По данным Глобальной системы показателей грудного вскармливания (Global Breastfeeding Scorecard) BО3, ни одна из 194 стран мира не соблюдает в полной мере рекомендации по культивированию грудного вскармливания (при этом тип грудного вскармливания не уточняется - естественное, бутилированное, донорское). Было выявлено, что только 40 \% детей в возрасте до 6 месяцев находятся на исключительном грудном вскармливании и лишь 23 страны имеют показатели исключительного грудного вскармливания, превышающие 60 \% (как правило, это азиатские и афрриканские страны). Согласно аналитическому отчету ВО3, инвестиции в размере 4,7 долл. США на одного новорожденного ребенка могут обеспечить к 2025 г. экономическую выгоду на сумму в 300 млрд долл. США. А отсутствие инвестиций в таких странах с переходной экономикой, как Китай, Индия, Индонезия, Мексика и Нигерия, приводят к 236000 случаев смерти детей в год и к экономическим потерям в размере 119 млрд долл. США [14].

По данным Росстата на 2015 г., в России только 42 \% женщин продолжают кормить своего ребенка грудным молоком от 3 до 6 месяцев и 41,1 \% - от 6 месяцев до 1 года. Таким образом, за 20 лет этот показатель снизился на 2,6 \% для детей от 3 до 6 месяцев жизни, но увеличился на 7,6 \% для детей от 6 месяцев до 1 года [15].

ВО3 активно развивает программы по продвижению грудного вскармливания не только в индустриально развитых странах, но и в развивающихся. Так, в 2018 г. было выпущено новое руководство «Защита, содействие и поддержка грудного вскармливания в медицинских учреждениях, обслуживающих матерей и новорожденных» в поддержку этой практики [16]. Многолетний опыт исследований по влиянию грудного вскармливания на общественное здоровье показал, что данная практика снижает заболеваемость кишечными инфекциями (некротизирующим энтероколитом, диареей), аллергией, инфекциями дыхательных путей, вероятность среднего отита, диабета 2-го типа, детской лейкемии и др. Более того, грудное вскармливание способствует уменьшению показателей внезапной детской смертности и увеличивает уровень интеллектуального развития ребенка. Примечательно, что для женщин грудное вскармливание является фрактором, снижающим вероятность рака груди, рака матки и яичников, диабета 2-го типа, послеродовой депрессии. По данным ВОЗ на 2015 г. зафиксировано, что 155 млн детей в возрасте до 5 лет имеют отставание в росте, 52 млн - низкое соотношение веса и роста, а 41 млн - избыточный вес и ожирение (без указания на тип вскармливания ребенка).

ВО3 ведет активную борьбу с рекламой молочных смесей в СМИ, считая их инструментом, сильно влияющим на отказ матерей от грудного вскармливания (в особенности молодых женщин до 25 лет). Российская статистика показывает, что женщины старше 30 лет осознанно относятся к грудному вскармливанию и делают этого чаще более молодых женщин. Кроме того, эта практика характерна для женщин как низших, так и высших групп благосостояния [17]. 
Считается, что агрессивная реклама молочных смесей транснациональными корпорациями и отсутствие поддержки со стороны общества (работодателя, старших родственников, отца ребенка и др.) являются главными причинами прекращения грудного вскармливания. Это нарушает Конвенцию о правах ребенка, согласно которой каждый ребенок грудного возраста и других возрастных групп имеет право на надлежащее питание. Поэтому в 1981 г. был введен Международный кодекс маркетинга заменителей грудного молока, призванный защитить потребителей от рекламы молочных смесей в СМИ, а также от бесплатного распространения демонстрационных образцов смесей, сосок и бутылок в родильных домах и перинатальных центрах. Он действует как свод рекомендаций, необязательных к исполнению.

В 2017 г. Общественной палатой РФ было проведено специальное слушание «Сохраним грудное вскармливание», где поднималась проблема возрождения культуры грудного вскармливания, особенно в крупных городах. По результатам слушания Государственной думе было рекомендовано разработать законопроект, «устанавливающий ограничения рекламы и мероприятий по продвижению детских молочных смесей» для детей от 0 до 12 месяцев. Однако, несмотря на регулирующие инструменты, «живые индустрии» продолжают развиваться, ставя во главу угла задачу индустриального производства человеческого белка в ущерб культуре естественного вскармливания молоком матери.

Ряд индустриально развитых стран сталкивается с проблемой низкого уровня грудного вскармливания. Так, в Великобритании, где эти показатели находятся на исключительно низком уровне - всего 1 \%, разрабатывается модель социальной политики с тремя вариантами развития событий, от негативного до позитивного, с целью улучшения качества трудовых ресурсов для будущего экономического роста страны. В общей сложности социальная политика внедрения программ грудного вскармливания позволяет сократить бюджетные расходы на лечение четырех острых заболеваний (кишечных инфекций, инфекций нижних дыхательный путей, среднего отита, некротизирующего энтероколита) у младенцев на 17 млн фунтов ежегодно. Также практика грудного вскармливания позволяет уменьшить численность детей с ожирением на $5 \%$, что равноценно экономии в 1,6 млн фрунтов [18].

В целом рост уровня грудного вскармливания на 1 \% означает экономический рост Великобритании на 278 млн фунтов на 1 человека на протяжении всей его жизни. Стоимость такой социальной программы составляет 446,300 фунтов в первый год внедрения и 329,300 фунтов в последующие годы [19].

Схожих взглядов придерживаются и другие европейские исследователи. Так, М. Бартик и А. Рейнхолд полагают, что увеличение продолжительности грудного вскармливания до 6 месяцев для 90 \% младенцев позволяет снизить расходы в США на 3,35 млрд долл. США [20]. Дрейн считает, что в Австралии грудное вскармливание детей до 3 месяцев на уровне $80 \%$ родившихся снижает государственные расходы на 9 млн австралийских долларов. Ф.Л. Бачнер и соавторы утверждают, что в Нидерландах обеспечение грудным вскармливанием детей до 6 месяцев на уровне 100 \% позволяет сэкономить 250 евро на каждом новорожденном [21]. По мнению А. Катанео, полное грудное вскармливание до 3 месяцев, а в последующем смешанное позволит сберечь 160 евро на человека для итальянской системы здравоохранения [22].

Таким образом, практика грудного вскармливания способствует снижению уровня заболеваемости 45 видами заболеваний матери и ребенка. Среди наиболее дорогостоящих для ведения с точки зрения государственных расходов находятся рак яичников и диабет 2-го типа у матери, астма, сердечно-сосудистые заболевания, целиакия, лейкемия, сепсис и диабет 2-го типа у ребенка [23, р. 86-88].

В России, по оценке Л. Абольян, председателя Совета Общественного движения Российской ассоциации врачей, благодаря грудному вскармливанию можно предотвратить детскую смертность до 5 лет на более чем 823 тыс. чел. и женскую смертность от рака молочной железы на 20 тыс. ежегодно. Более того, за счет интеллектуальных способностей людей, выкормленных в детстве грудным молоком, можно увеличить валовой национальный доход России на 0,5 \% [24]. По данным Союза педиатров России, в последнее десятилетие доля детей, находящихся на грудном вскармливании до года, в крупных городах остается невелика - например, 33,8-35 \% для Санкт-Петербурга [25]. В целом педиатрическое сообщество России разделяет мнение ВОЗ, что ребенок должен вскармливаться грудью до достижения 2 и более лет. На данный момент доступны только статистические данные о практике грудного вскармливания в РФ до 6 и до 12 месяцев, поэтому оценить долю детей, находящихся на грудном вскармливании до 24 месяцев и более, невозможно.

Вместе с тем исследование, проведенное К. Детвайлер, показывает, что продолжительное грудное вскармливание от 2,5 до 7 лет непосредственным образом влияет на здоровье человека в течение всей его жизни, а не только обеспечивает выживаемость в первые несколько лет [26]. Важно, что даже на втором году жизни в грудном молоке содержится необходимое количество 
витамина А в легкоусвояемой форме - главного витамина роста, объем которого трудно восполнить из внешних источников [27]. По мнению А. Базановой, заведующей отделением детей раннего возраста Детского медицинского центра Управления делами Президента РФ, грудное вскармливание обеспечивает пищевые потребности ребенка до 6 месяцев на $100 \%$, от 6 до 12 месяцев - на 50 \%, от 1 года до 3 лет - на 30 \% [28].

По мнению Т.А. Гебрейесуса, Генерального директора ВОЗ, «грудное вскармливание обеспечивает детям по возможности наилучшее начало жизни. Грудное молоко действует как первая вакцина для ребенка, защищая его от потенциально смертельных болезней и предоставляя ему все питательные вещества, необходимые для выживания и процветания» [29]. Инициатива по грудному вскармливанию ВОЗ среди прочего борется за введение продолжительного оплачиваемого отпуска по семейным обстоятельствам и проведение в жизнь политики поощрения грудного вскармливания на рабочих местах как инструмента защиты материнства в рамках Международной организации труда (Конвенция об охране материнства № 183 была принята в июне 2000 г.).

Более ранние исследования 1990-х гг. показывают, что в развитых странах необходимость для женщины в скором времени вернуться на рынок труда является главной причиной отказа от грудного вскармливания [30]. Грудное вскармливание и трудовую занятость женщин нельзя рассматривать изолированно от социальной политики (размера пособий по беременности и родам, медицинского страхования, уровня заработной платы, мер по уходу за ребенком). К примеру, С. Готтшанг показала, что снижение доли грудного вскармливания в Китае было вызвано тем, что $90 \%$ женщин трудоспособного возраста в городах были заняты на рынке труда, а также резкой экспансией рынка детских молочных смесей [31]. Заметим, что уровень занятости женщин 20-49 лет в России, имеющих детей дошкольного возраста (0-6 лет), составляет в 2016 г. 64,9 \% [32, с. 16].

Сегодня отношение к грудному вскармливанию неоднозначное. В ряде стран существует общественное неприятие кормящих женщин в публичных местах (несмотря на легальность этой практики), это считается аморальным (особенно со стороны мужчин), актом нудизма. В то же время кормление ребенка из бутылочки не вызывает подобного осуждения. Как ответная реакция возникает глобальное социальное движение по грудному вскармливанию, призванное отстоять женские репродуктивные права и право на безопасное питание для ребенка. С 2012 г. активно развивается международное движение Free the nipple за право женщин показывать обнаженную грудь в общественном месте, в том числе с целью покормить младенца.

Негативное отношение к грудному вскармливанию подкрепляется научными исследованиями, призванными доказать положительное влияние грудного вскармливания на развитие заболевания раком у женщин, в частности при кормлении последнего ребенка. Помимо этого, декларируется, что запретом на грудное вскармливание выступают инфекции: туберкулез, гепатит В (разрешено ВОЗ после вакцинации) и ВИЧ (разрешено ВОЗ до 1,5 месяцев) и наиболее изученные химические загрязняющие вещества (диоксины, полихлорированные бифенилы, хлорорганические пестициды) в грудном молоке [33]. Влияние лекарств на грудное вскармливание, как правило, не изучается. Однако при любом заболевании женщине рекомендуется прекратить грудное вскармливание.

Теневой стороной дискурса о грудном и бутилированном вскармливании является проблема маркетизации грудного молока. В социальных сетях можно встретить объявления о продаже грудного молока. Как пример - группа «ВКонтакте» «Грудное молоко, кормилицы, продам, отдам, куплю» (https://vk.com/club56989901). Средняя рыночная цена за 100 мл составляет от 150 до 500 р. для свежего молока и от 100 р. для замороженного. В среднем ежедневное предложение грудного молока составляет 500 мл, а потребность ребенка раннего возраста - 1000 мл в день. (Для сравнения 100 мл молочной смеси на основе коровьего молока стоит 9-17 р. при условии использования бесплатной воды (диапазон цен дан для торговых марок от эконом-класса до класса премиум), в то время как 100 мл коровьего молока 3,5 \% - от 6 до 22,5 р., а 100 мл коровьего детского молока 3,2 \% - 9-9,5 р. (По данным сервиса доставки продуктов iGooods: https://igooods.ru/products.)

Грудное молоко можно заказать с учетом соблюдения женщиной-донором антиаллергенной диеты или реже религиозной диеты (например, употребления только халяльной пищи), приема специальных витаминов (например, израильского производства), разного возраста ребенка женщины (чтобы подобрать молоко по необходимому сроку лактации), на продолжительный срок (2-4 месяца), со скидкой для оптовых закупок (для замороженного молока), с использованием различных технологий сцеживания (престижными считаются электрические молокоотсосы Medela и Avent) и тары хранения (стекло/пластик).

Среди причин, почему женщины предлагают свое грудное молоко, они называют избыток молока (в том числе замороженного для личных нужд) и нежелание своего ребенка сосать, нехватку средств для покупки своему ребенку детских консервов при введении прикорма или одежды, возможность постоянного заработка со стороны малообеспеченных женщин и трудовых мигранток 
и др. Объявления размещаются напрямую от женщин или их мужей. Некоторые объявления содержат информацию, что толчком к началу продаж своего молока стала рекомендация педиатра. Также часто можно встретить жалобы на страницах социальных сетей об обращении за молоком не нуждающихся женщин с младенцами, а мужчин для личных целей. Следует отметить, что качество, подлинность и безопасность подобного грудного молока не контролируются никакими внешними организациями. Группа в социальной сети служит платформой для поиска доноров и клиентов, реже встречаются предложения об услугах кормилец и о безвозмездной передаче молока, как правило, старого, замороженного в домашних условиях при $-4{ }^{\circ} \mathrm{C}$. В среднем молоко хранится до 1 месяца, однако в объявлениях можно встретить более «старое», 6-8-месячное, которое также пользуется спросом. Важно отметить, что все участники социальной сети разделяют мнение, что донорское молоко полезнее сухих молочных смесей.

Помимо социальных сетей, с 2010 г. в России действует Международный волонтерский проект «Грудное молоко от мамы к маме» (Human Milk for Human Babies), в рамках которого происходит обмен между матерями донорским молоком (milkmama.org). В 2014 г. в Москве на базе Научного центра здоровья детей РАMН при поддержке транснациональной компании Philips Avent открылся первый банк донорского молока. Всего в мире насчитывается более 500 банков донорского молока. Его основными реципиентами становятся недоношенные дети и дети в возрасте до 1 месяца, для которых высок риск смертности от некротирующего энтероколита, сепсиса, бронхолегочной дисплазии, ретинопатии и др. За год работы было собрано более 148 л донорского молока от 76 кормящих женщин для 55 младенцев [34]. В 2016 г. банк грудного молока стал лауреатом премии «Золотой медвежонок» в рамках VI Национальной премии в сфере товаров и услуг для детей как социально значимый проект.

Если для российского банка донорского молока характерна безвозмездная основа отношений «донор - реципиент», то для американского передача молока осуществляется на платной основе (для покрытия организационных издержек). Однако все остальные медицинские услуги в области перинатологии и неонатологии и др. в Научном центре здоровья детей также осуществляются на платной основе, включая обучение матери технике кормления и уходу за новорожденным ребенком (2000р.). Эта практика, как правило, является бесплатной в районных женских консультациях и родильных домах, особенно в медицинских учреждениях типа «Больница, доброжелательная к ребенку», реализующих политику поддержки и пропаганды грудного вскармливания ВОЗ/ЮНИСЕФ (1991).

Таким образом, Россия включается в международный процесс капитализации грудного молока. Дискурс о высокой нутриологической и социальной ценности грудного вскармливания, инициированный международными организациями здравоохранения, превращает грудное молоко из естественной практики питания ребенка раннего возраста в редкий и особо ценный ресурс. Оно мифологизируется как исключительно полезная еда, необходимая для «выращивания» человека - создателя ВВП. Грудное молоко аккумулируется в национальных и международных банках донорского молока, поддерживаемых транснациональными корпорациями. Параллельно с этим процессом развивается и теневой «белый рынок» производителей, для которых продажа грудного молока является источником дохода.

Подобное положение вещей противостоит точке зрения Р. Барта, который в своей работе «Мифологии» (эссе «Вино и молоко») (1957) исследовал напитки как социальные конструкты современности. Так, он указывал на особенность вина (национального достояния, напитка-тотема, инструмента социальной интеграции, как он его называл) составлять основу производственного капитализма Франции, в то время как молоко выступает в той же роли для Голландии и Швейцарии [35]. Действительно, именно молоко и его производные обеспечили признание этих экономик на международных рынках. Эти страны сумели капитализировать молоко (т. е. создать такую социальную систему производства и переработки, когда каждый фермер в стране считал это прибыльным бизнесом) и превратили его в рыночный товар, предварительно пастеризовав и высушив молоко, обеспечив тем самым возможность его транспортировки в глобальных масштабах. Результатом этого сегодня является лидерство молочных транснациональных компаний швейцарской Nestle и голландской Nutricia (Danone) на международных рынках. Их детские молочные смеси совершили революцию в социальных практиках питания детей раннего возраста. Естественное грудное вскармливание было десакрализировано, ребенок был физически и социально оторван от матери. Вырастить ребенка стало возможным при помощи быстрорастворимого сухого молока и соски. Процесс детского питания был рационализирован - нужное количество порошка нужно было развести в бутылочке и кормить по часам. Участвовать в питании детей смогли не только мать и близкие родственницы, но и внешние попечители. А женщина смогла вернуться к своей трудовой деятельности в кратчайшие сроки - через несколько дней после рождения ребенка. 
Сегодня Трудовой кодекс РФ закрепляет за женщинами право выкормить ребенка до достижения им 1,5 лет. При этом женщина может уже возобновить трудовую деятельность или еще находиться в отпуске по уходу за ребенком. На практике продолжительность грудного вскармливания для женщин оказывается в пределах 11 месяцев. Однако никаких обязательств работодателя по организации кормления на рабочем месте не предусматривается. Наличие комнаты матери и ребенка является скорее исключением, чем распространенной социальной практикой. В 2017 г. Роспотребнадзор разработал проект СанПиНа «Санитарно-эпидемиологические требования к условиям труда женщин», в соответствии с которым работодатель будет обязан предоставить женщине с ребенком до 1,5 лет оборудованную комнату для кормления. Однако где и с кем будет находиться грудной ребенок в остальное рабочее время, остается неясным. Как результат, ребенок раннего возраста с большой вероятностью будет переводиться на искусственное или донорское вскармливание.

Важно отметить, что большая доля женщин, как правило, занята в сфере услуг, что предполагает наличие большого количества социальных контактов и, как следствие, высокий риск инфекционных заболеваний. При сниженном иммунитете во время лактации это приводит к повышению заболеваемости ОРЗ и др. как самих женщин, так и их детей, что оборачивается перерывами в работе по причине болезни (и угрозой скорого увольнения), приемом лекарственных средств, несовместимых с грудным вскармливанием. В итоге это определяет высокий спрос на искусственные молочные смеси и донорское молоко.

Так, грудное вскармливание при его высокой социальной ценности, декларируемой международными и национальными организациями здравоохранения, является недоступной социальной практикой питания детей рабочего (среднего) класса в силу социально-экономических условий. Оно становится прерогативой низших и высших социальных слоев благодаря капиталу времени, необходимому для выкармливания ребенка. Неработающие женщины низших социальных слоев, хотя и не обладают достатком, чтобы получать качественное питание во время лактации, могут иметь основной или дополнительный заработок, продавая свое грудное молоко или становясь кормилицами и получая дополнительные средства на питание от клиентов для улучшения состава молока. Женщины высших социальных слоев при наличии желания и хорошем состоянии здоровья обладают всем необходимым для успешного грудного вскармливания. Даже если они ведут активную трудовую или социальную жизнь, они имеют возможность проявлять гибкость в управлении своим временем и организации рабочего места. Однако естественное грудное вскармливание не является общепризнанной социальной практикой, в отличие от искусственного или донорского грудного вскармливания, и в силу культурных условий. Оно не дает женщине легитимного социального статуса, в отличие, скажем, от донорства.

По фракту развивающаяся международная система «молочного капитализма» (как искусственных детских смесей, так и донорского молока) определяет социальные практики питания детей раннего возраста. Вокруг проблемы грудного вскармливания складывается культура бутилированного вскармливания: речь идет о кормлении ребенка при помощи бутылки, либо грудным молоком матери (ушедшей на работу) или донора, либо детскими смесями на основе молока животных или растительного молока (milk-free infant formula - соевые смеси при нетолерантности к молоку и лактозе). Отношения близости между матерью и ребенком, существующие при естественном грудном вскармливании, разрываются и приобретают новую экономическую ценность [36]. Происходит переход к технологичному кормлению и растущему спросу на сакральные биоресурсы - человеческое молоко как важный биологический и социальный ресурс, что превращает естественное грудное вскармливание в альтернативную социальную практику питания детей раннего возраста.

\section{Ссылки и примечания:}

1. Исследование выполнено при поддержке гранта РФФИ 17-03-00631-ОГН/18 «Повседневные практики питания и общественное здоровье населения (на примере Санкт-Петербурга и Ленинградской области)».

2. Baumslag N., Michels D.L. Milk, Money, and Madness: The Culture and Politics of Breastfeeding. Westport, CT, 1995. 288 p.

3. Womanly Art of Breastfeeding / ed. by J. Torgus, G. Gotsch ; LA Leche League Intl. 2004. 463 p.

4. Rubin S. The ABCs of Breastfeeding: Everything a Mom Needs to Know for a Happy Nursing Experience. N. Y., 2008. 288 p.

5. Newman J. Breastfeeding: Empowering Parents. N. Y., 2018. $471 \mathrm{p}$

6. Shortall J. Work. Pump. Repeat: The New Mom's Survival Guide to Breastfeeding and Going Back to Work. N. Y., 2015. 208 p.

7. Hale T.W., Rowe H.E. Medications and Mothers' Milk 2017. 17 ${ }^{\text {th }}$ ed. N. Y., 2017. 1096 p.

8. West D., Marasco L. The Breastfeeding Mother's Guide to Making More Milk / forew. by M. Sears. N. Y. ; Chicago ; San Francisco, 2008. $304 \mathrm{p}$.

9. Schnell A. Breastfeeding without Birthing: A Breastfeeding Guide for Mothers through Adoption, Surrogacy, and Other Special Circumstances. Amarillo, 2013. 242 p.

10. Infant Feeding Practices: A Cross-Cultural Perspective / ed. by P. Liamputtong. N. Y., 2011.372 p. https://doi.org/10.1007/978-1-4419-6873-9.

11. Wambach K., Riordan J. Breastfeeding and Human Lactation. Enhanced $5^{\text {th }}$ ed. Jones \& Bartlett Learning, 2015. 966 p.

12. Wilson-Clay B. The Breastfeeding Atlas. $6^{\text {th }}$ ed. Manchaka, TX, 2017. 
13. Lawrence R.A., Lawrence R.M. Breastfeeding: A Guide for the Medical Profession. $8^{\text {th }}$ ed. Philadelphia, PA, 2015. 992 p. ; Walker M. Breastfeeding Management for the Clinician: Using the Evidence. $4^{\text {th }}$ ed. Burlington, MA, 2016. $700 \mathrm{p}$.

14. Дети и матери во всем мире страдают из-за отсутствия инвестиций в поддержку грудного вскармливания [Электронный ресурс] // Всемирная организация здравоохранения. 2017. 1 авг. URL: http://www.who.int/mediacentre/news/releases/2017/lack-investment-breastfeeding/ru/ (дата обращения: 07.10.2017).

15. Лукоянова О.Л. Научное обоснование и разработка новых технологий организации и поддержки грудного вскармливания : дис. ... д-ра мед. наук. М., 2016. 259 с.

16. Protecting, Promoting and Supporting Breastfeeding in Facilities Providing Maternity and Newborn Services: The Revised Baby-friendly Hospital Initiative [Электронный pecypc] / ed. by P. Howes. Geneva, 2018. 54 p. URL: http://www.who.int/nutrition/publications/infantfeeding/bfhi-implementation-2018.pdf (дата обращения: 11.10.2018).

17. Сакевич В. Грудное вскармливание в России [Электронный ресурс] // Демоскоп Weekly. 2015. № 651-652. URL: http://www.demoscope.ru/weekly/2015/0651/reprod02.php (дата обращения: 10.05.2018).

18. Preventing Disease and Saving Resources: The Potential Contribution of Increasing Breastfeeding Rates in the UK [Электронный ресурс]. 2012. October. URL: https://www.unicef.org.uk/wp-content/uploads/sites/2/2012/11/Preventing_disease_saving_resources.pdf (дата обращения: 10.05.2018).

19. Ibid

20. Bartick M., Reinhold A. The Burden of Suboptimal Breastfeeding in the United States: A Pediatric Cost Analysis // Pediatrics. 2010. Vol. 125, iss. 5. https://doi.org/10.1542/peds.2009-1616.

21. Büchner F.L., Hoekstra J., Rossum C.T.M. van. Health Gain and Economic Evaluation of Breastfeeding Policies: Model Simulation [Электронный ресурc]. 2007. URL: https://www.rivm.nl/bibliotheek/rapporten/350040002.pdf (дата обращения: 11.10.2018)

22. Cataneo A. Protecção, promoção e suporte ao aleitamento materno na Europa: um projecto em acção [Электронный ресурс]. 2004. URL: https://iblce.org/wp-content/uploads/2017/06/eu-blueprint-portuguese.pdf (дата обращения: 11.10.2018).

23. Preventing Disease and Saving Resources ... P. 86-88.

24. Резник И. Грудное вскармливание в России будет регулироваться отдельным законом [Электронный ресурс] // Медицинский портал. 2017. 28 нояб. URL: http://medportal.ru/mednovosti/news/2017/11/28/091milk/ (дата обращения: 11.10.2018)

25. Санкт-петербургский проект «Охрана и поддержка грудного вскармливания в мегаполисе» [Электронный ресурс] // Союз педиатров в России. 2009. URL: http://www.pediatriya-spb.ru/for_parents/breast_feeding_proect.html (дата обращения: 11.10.2018).

26. Esterik P. van. Contemporary Trends in Infant Feeding Research // Annual Review of Anthropology. 2002. Vol. 31. P. 257278. https://doi.org/10.1146/annurev.anthro.31.040402.085428.

27. Complementary Feeding. Family Foods for Breastfed Children [Электронный ресурс] / Department of Nutrition for Health and Development ; World Health Organization. 2000. URL: http://apps.who.int/iris/bitstream/handle/10665/66389/WHO NHD 00.1.pdf?sequence=1 (дата обращения: 11.10.2018).

28. Недюк М. Минздрав поддержал кормящих матерей [Электронный ресурс] // Известия. 2017. 19 сент. URL: https://iz.ru/645771/mariia-nediuk/minzdrav-populiariziruet-grudnoe-vskarmlivanie (дата обращения: 12.10.2018).

29. Дети и матери во всем мире ...

30. Killien M.G. Postpartum Return to Work: Mothering Stress, Anxiety, and Gratification // The Canadian Journal of Nursing Research. 1998. Vol. 30, no. 3. P. 53-66.

31. Gottschang S.Zh. Maternal Bodies, Breastfeeding, and Consumer Desire in Urban China // Medical Anthropology Quarterly. International Journal for the Analysis of Health. 2007. Vol. 21, iss. 1. P. 64-80. https://doi.org/10.1525/maq.2007.21.1.64.

32. Цит. по: Фомина С.В. Содействие занятости женщин, имеющих несовершеннолетних детей : выпускная квалификационная работа. Казань, 2017. 71 с.

33. Pronczuk J., Moy G., Vallenas C. Breast Milk: An Optimal Food // Environmental Health Perspectives. 2004. Vol. 112, no. 13. P. A722-A723. https://doi.org/10.1289/ehp.112-a722.

34. Банк донорского грудного молока за первый год работы помог более чем 50 маленьким пациентам [Электронный pecypc]. 2016. URL: https://vsp.spr-journal.ru/jour/article/download/1568/572 (дата обращения: 11.10.2018).

35. Барт Р. Мифологии. 4-е изд. М., 2017. 352 c.

36. Zelizer V.: 1) Pricing the Priceless Child: The Changing Social Value of Children. Princeton, 1985. 296 p. ; 2) The Purchase of Intimacy. Princeton, 2007. 369 p.

\section{References:}

Bart, R 2017, Mythologies, 4th ed., Moscow, 352 p., (in Russian).

Bartick, M \& Reinhold, A 2010, 'The Burden of Suboptimal Breastfeeding in the United States: Pediatric Cost Analysis', Pediatrics, vol. 125, iss. 5. https://doi.org/10.1542/peds.2009-1616.

Baumslag, N \& Michels, DL 1995, Milk, Money, and Madness: The Culture and Politics of Breastfeeding, Westport, Connecticut, $288 \mathrm{p}$.

Büchner, FL, Hoekstra, J \& Rossum, CTM van 2007, Health Gain and Economic Evaluation of Breastfeeding Policies: Model Simulation, viewed 11 October 2018, <https://www.rivm.nl/bibliotheek/rapporten/350040002.pdf>

Cataneo, A 2004, Proteç̧ão, promoção e suporte ao aleitamento materno na Europa: um projecto em acção, viewed 11 October 2018, <https://iblce.org/wp-content/uploads/2017/06/eu-blueprint-portuguese.pdf>, (in Portuguese)

Esterik, P van 2002, 'Contemporary Trends in Infant Feeding Research', Annual Review of Anthropology, vol. 31, pp. 257-

278. https://doi.org/10.1146/annurev.anthro.31.040402.085428.

Fomina, SV 2017, Promoting the Employment of Women with Minor Children, graduation thesis, Kazan, 71 p., (in Russian). Gottschang, SZh 2007, 'Maternal Bodies, Breastfeeding, and Consumer Desire in Urban China', Medical Anthropology Quar-

terly. International Journal for the Analysis of Health, vol. 21, iss. 1, pp. 64-80. https://doi.org/10.1525/maq.2007.21.1.64.

Hale, TW \& Rowe, HE 2017, Medications and Mothers 'Milk 2017, 17th ed., New York, 1096 p.

Howes, P (ed.) 2018, Protecting, Promoting and Supporting Breastfeeding in Facilities Providing Maternity and Newborn Services: The Revised Baby-friendly Hospital Initiative, Geneva, 54 p. viewed 11 October 2018, <http://www.who.int/nutrition/publications/infantfeeding/bfhi-implementation-2018.pdf>

Killien, MG 1998, 'Postpartum Return to Work: Mothering Stress, Anxiety, and Gratification', The Canadian Journal of Nursing Research, vol. 30, no. 3, pp. 53-66. $992 \mathrm{p}$

Lawrence, RA \& Lawrence, RM 2015, Breastfeeding: A Guide for the Medical Profession, 8th ed. Philadelphia, Pennsylvania, 
Liamputtong, P (ed.) 2011, Infant Feeding Practices: A Cross-Cultural Perspective, New York, 372 p. https://doi.org/10.1007/978-1-4419-6873-9.

Lukoyanova, OL 2016, Scientific Justification and Development of New Technologies for Arranging and Supporting Breastfeeding, D. Phil. thesis, Moscow, 259 p., (in Russian).

Nedyuk, M 2017, 'Ministry of Health Supported Nursing Mothers', Izvestiya, September 19, viewed 12 October 2018, <https://iz.ru/645771/mariia-nediuk/minzdrav-populiariziruet-grudnoe-vskarmlivanie>, (in Russian).

Newman, J 2018, Breastfeeding: Empowering Parents, New York, 471 p.

Preventing Disease and Saving Resources: The Potential Contribution of Increasing Breastfeeding Rates in the UK 2012, October, pp. 86-88, viewed 10 May 2018, <https://www.unicef.org.uk/wp-content/uploads/sites/2/2012/11/Preventing_disease_saving_resources.pdf>.

Pronczuk, J, Moy, G \& Vallenas, C 2004, 'Breast Milk: An Optimal Food', Environmental Health Perspectives, vol. 112, no. 13, pp. A722-A723. https://doi.org/10.1289/ehp.112-a722.

Reznik, I 2017, 'Breastfeeding in Russia Will Be Governed by a Separate Law', Meditsinskiy portal, November 28, viewed 11 October 2018, <http://medportal.ru/mednovosti/news/2017/11/28/091milk/>.

Rubin, S 2008, The ABCs of Breastfeeding: Everything a Mom Needs to Know for a Happy Nursing Experience, New York, $288 \mathrm{p}$.

Sakevich, V 2015, 'Breastfeeding in Russia', Demoskop Weekly, no. 651-652, viewed 10 May 2018, <http://www.demoscope.ru/weekly/2015/0651/reprod02.php>, (in Russian).

Schnell, A 2013, Breastfeeding without Birthing: A Breastfeeding Guide for Mothers through Adoption, Surrogacy, and Other Special Circumstances, Amarillo, 242 p.

Shortall, J 2015, Work. Pump. Repeat: The New Mom's Survival Guide to Breastfeeding and Going Back to Work, New York, $208 \mathrm{p}$.

Torgus, J \& Gotsch, G (eds.) 2004, Womanly Art of Breastfeeding, Los Angeles, Leche League Intl., 463 p.

Walker, M 2016, Breastfeeding Management for the Clinician: Using the Evidence, 4th ed., Burlington, Massachusetts, $700 \mathrm{p}$. Wambach, K \& Riordan, J 2015, Breastfeeding and Human Lactation, Enhanced 5th ed., Jones \& Bartlett Learning, 966 p.

West, D, Marasco, L \& Sears, M 2008, The Mother's Guide to Making More Milk, New York, Chicago, San Francisco, 304 p. Wilson-Clay, B 2017, The Breastfeeding Atlas, 6th ed., Manchaka, Texas.

Zelizer, V 1985, Pricing the Priceless Child: The Changing Social Value of Children, Princeton, $296 \mathrm{p}$.

Zelizer, V 2007, The Purchase of Intimacy, Princeton, 369 p. 